\title{
LOS JESUITAS: \\ DE LAS POSTRIMERÍAS A LA MUERTE EJEMPLAR
}

\author{
POR \\ JAVIER BURRIEZA SÁNCHEZ \\ Instituto de Historia. CSIC*
}

\begin{abstract}
RESUMEN
La Compañía de Jesús se hallaba cercana al enfermo que agonizaba o al condenado a muerte por un delito cometido. Un objetivo principal del trabajo de los jesuitas era lograr, no sólo su propia salvación, sino la de los prójimos. La dirección espiritual en los últimos momentos de una vida, que debía prepararse para la buena muerte, era un medio más para conseguir este objetivo. De las obras escritas para ello, de las muertes diversas como distintas eran las personas y de los destinos después del «final», siempre desde los ojos jesuíticos, trataremos en este artículo.

Palabras ClaVE: Compañía de Jesús, muerte, Siglos XVI, XVII y XVIII, jesuitas, religiosidad popular, dirección espiritual, Confesión, Reforma católica, Iglesia católica.
\end{abstract}

\section{THE JESUITS:}

\section{FROM THE END OF THE LIFE TO AN EXEMPLARY DEATH}

\section{ABSTRACT}

The Society of Jesus was near the sick person who was in the throes of death or the condemned man for a committed crime. The principal aim of the Jesuits

\footnotetext{
* Esta ponencia se incluye dentro de las publicaciones del proyecto de investigación «Dimensión política de la formación del clero inglés en la Monarquía hispánica (siglos XVI-XVIII): entre la guerra, la paz y la indiferencia» (contrato Juan de la Cierva), dentro del proyecto de investigación, cuyo investigador principal es el Dr. Enrique García Hernán, bajo el título «La comunidad irlandesa en la Monarquía hispánica (siglos XVI-XVIII): identidad e integración social» (MEC. Subdirección General de Proyectos de Investigación, Ref. HUM2005-05763 / HIST).
} 
was to get, not only their own salvation, but also of other people's. The spiritual direction in the last moments of a life, which had to get ready for a good death, was another way to get this target. Among all the works written for it, among the different ways of dying as well as people are different, and the destinies after their death, we will deal with this essay, always from the Jesuits eyes.

KEY WORDS: Society of Jesus; death; 16th century, 17th century and18th century; Jesuits; Popular religiosity; spiritual direction; Confession; Catholic Reformation; Catholic Church.

Recibido/Received 16-05-2008

Aceptado/Accepted 30-12-2008

Decía el jesuita Francisco de Arana que «clausurar una buena vida y comenzar una bienaventurada eternidad, está al arbitrio del hombre y cae debajo de su elección. El medio más oportuno que conduce a esta elección es la preparación anticipada de la muerte» 1 . La forma de combatir el carácter inesperado de la muerte era elegir cuanto antes el modo de afrontarla adecuadamente. Arana proponía una preparación diaria, semanal y mensual, a través de ejercicios concretos como el examen de conciencia, imaginándose la muerte en el atardecer del día y haciendo memoria de la misma a través de un retiro mensual.

Entre los muchos estereotipos que se han venido asociando a la Compañía de Jesús, instituto religioso fundado por Ignacio de Loyola y aprobado por el papa Paulo III en 1540, ha destacado la condición de que sus miembros eran maestros del tenebrismo, habilidosos en el recurso de la recreación de las postrimerías, auténticos cronistas de la gloria, el purgatorio y el temible infierno, en definitiva de los últimos estados del hombre -muerte, juicio, infierno y gloria, los novísimos-. Imágenes que parecían venir subrayadas por aquellos sermones y relatos de misiones populares, donde los más rigoristas de los predicadores no cesaban de representar los últimos momentos de la vida de un pecador y hacían, incluso, hablar a los muertos, para convencer a los vivos que todavía estaban a tiempo de cambiar de vida, giro radical que les evitaría quemarse en las «llamas del infortunio» ${ }^{2}$. El escenario de fondo de todo lo que vamos a desarrollar es una sociedad profundamente sacralizada, donde la manifestación de lo religioso se plasmaba también en los aspectos más alejados de lo espiritual. Son, pues, rasgos de la religiosidad colectiva de los españoles ${ }^{3}$.

${ }^{1}$ Francisco ARANA, Muerte prevenida, cristiana preparación para una buena muerte. Sobre aquellas palabras del Evangelio: «Es vos estote parati, quia, qua hora non putatis, Filius hominis veniet», Sevilla, 1736.

2 Teófanes EGIDO, «Los sermones: retórica y espectáculo», en Trabajo y Ocio en la época moder$n a$, dirigido por Luis A. Ribot García y Luigi de Rosa, Madrid, Actas, 2001, pp. 87-110.

3 Teófanes EgIDo LóPEZ, «La religiosidad colectiva de los vallisoletanos», en Historia de Valladolid (V), Valladolid en el siglo XVIII, Valladolid, 1984, pp. 159-244. Máximo GARCÍA FERnÁNDEZ, «Actitudes ante la muerte, religiosidad y mentalidad en la España moderna. Revisión historiográfica», Hispania, 176 (1990), pp. 1073-1090.

Hispania Sacra, LXI

124, julio-diciembre 2009, 513-544, ISSN: 0018-215-X 
PlANTEAMIENTO DE UN DISCURSO SOBRE LA MUERTE: LA NECESIDAD DE UNA VIDA ESPIRITUAL ADECUADA

En los Ejercicios Espirituales, la obra capital de la espiritualidad ignaciana, en las meditaciones de la muerte y del juicio, la conocida composición de lugar invitaba a que el ejercitante imaginase el momento de su propio fallecimiento, no por un gusto masoquista, sino por una revisión de su propia cotidianidad 4 . Se trataba de experimentar el carácter pasajero de la vida terrena, de un cuerpo que pierde todo su valor una vez que el alma hubiese salido de él. En esa misma línea habría que situar la famosa Meditación décima, «De lo que sucede al cuerpo después de la muerte y de la sepultura», escrita por el vallisoletano Luis de La Puente dentro de su éxito editorial, «Meditaciones Espirituales», cuya primera edición fue en $1605^{5}$.

De esta manera, las meditaciones de la muerte en los Ejercicios Espirituales se integraron en su discurso que, como orden religiosa, hacían para llamar a una elección adecuada del estado de vida, que entonces se consideraba virtuoso, y no como un recreo y gusto por lo macabro ${ }^{6}$. Los Ejercicios, repartidos en semanas, en la primera de ellas, el ejercitante se debía encontrar con Dios y para ello necesitaba recogimiento interior y abandono del bullicio. Se meditaba sobre el pecado personal y el del mundo, reconociéndose el hombre en el camino de la perdición. Ahí es donde se ubicaba la meditación de la muerte, entendida desde la caducidad de la vida, contrapuesta a la misericordia y el amor demostrado por Dios. Los días de Ignacio de Loyola y los de las generaciones posteriores fueron los de la preocupación por la salvación del alma, no solamente en el momento de la muerte, sino a lo largo de toda la vida. También Ignacio de Loyola se había formado en la escatología popular de los citados cuatro novísimos, subrayando la necesidad de «estar siempre en regla con Dios» ${ }^{7}$.

\footnotetext{
${ }_{4}$ «Quinto exercicio es meditacion del infierno; contiene en sí, después de la oración preparatoria y dos preámbulos, cinco punctos y un coloquio», en Ejercicios Espirituales, Primera semana, en Obras completas de Ignacio de Loyola, Madrid, BAC, 1997, pp. 241-242.

${ }^{5}$ Luis de La Puente, Meditaciones Espirituales del Venerable Padre..., de la Compañía de Jesús, Barcelona, imprenta María Ángela Martí, viuda, 1757, pp. 100-105. La primera edición se editó en Valladolid, en la imprenta Juan de Bostillo, en 1605: Meditaciones de los Misterios de Nuestra Sancta Fe, con la práctica de la oración mental sobre ellos.

6 Íñigo ArRAnz RoA, La atención a pobres y menesterosos en la Provincia de Castilla de la Compañía de Jesús 1550-1650, Tesis doctoral inédita leída en la Universidad Pontifica de Comillas para la obtención de Doctor, bajo la dirección del Dr. Manuel Revuelta González, Madrid, 2004, p. 701.

${ }^{7}$ I. IGLESIAS, «La escatología que vivió Ignacio de Loyola. Aspectos anticipadores», Manresa 68 (1996/3), pp. 261 y ss.
} 


\section{Concepto de la muerte en el discurso de la Compañía de Jesús}

La expresión, «ayudar a bien morir» ${ }^{8}$ no fue un término creado para y por los trabajos de la Compañía de Jesús, aunque su fundador lo incluyó como uno de los medios fundamentales para ayudar a los prójimos. Su secretario, el padre Juan de Polanco, consideraba que para morir bien solamente existía una oportunidad, no pudiéndose corregir los errores que se hubiesen cometido ${ }^{9}$. La presencia de un jesuita, en los últimos momentos de una vida, debía estar plagada de un léxico propio desde el cual se intentase eliminar el temor, sustituyéndolo por el consuelo, la entrega de la mano, la ayuda y el ánimo.

Dos campos tenían los miembros de la Compañía de atender en la muerte. El primero era práctico, mucho más fácil de percibir, no reduciéndose a los que habitualmente se confesaban o eran dirigidos por jesuitas. Abarcaban en esta atención a los que agonizaban en hospitales ó esperaban en las cárceles a que se cumpliese una sentencia. Pero también podían atender a los que se encontraban al borde de la muerte a causa de la extensión de una de las frecuentes epidemias que asolaban la Europa del momento. Un segundo ámbito era el teórico, es decir, los jesuitas enseñando a otros -ya fuesen sacerdotes, miembros de otras religiones o congregantes- a ayudar a bien morir, a través de las páginas de los manuales, contando los miembros de la Compañía con una notable proporción en el conjunto del género, especialmente floreciente en el siglo XVII.

En realidad, lo que hacían era una desdramatización de la muerte, pues la englobaban en una realidad superior que era la existencia. Francisco de Borja, autor de uno de estos manuales y tercer prepósito general de la Compañía, hablaba de la muerte como recompensa y descanso de todo lo que se había vivido anteriormente. La muerte era cotidiana en aquellas realidades. Una cotidianidad que, como detalla Juan de Polanco, obligaba a prepararse diariamente para ella, teniendo un papel fundamental el ejercicio de las buenas obras, que culminaban en las disposiciones testamentarias. Se insistía mucho, en el discurso sobre la muerte, en que los malvados y persistentes vivían como si el final de la existencia no se fuese a producir nunca, como si nunca llegase avisando, cuando en realidad los que se negaban a convertirse les esperaba un final en consonancia con todo lo que habían cometido. Francisco de Borja recomendaba una frecuente memoria de la muerte durante el

${ }^{8}$ La tesis doctoral del mencionado Íñigo Arranz desarrolló este punto de la asistencia social. Íñigo ARRANZ RoA, La atención a pobres y menesterosos en la Provincia de Castilla de la Compañía de Jesús 1550-1650, Tesis doctoral inédita leída en la Universidad Pontificia de Comillas para la obtención del título de Doctor, bajo la dirección del Dr. Manuel Revuelta González, Madrid 2004, p. 701. Agradezco haber accedido a la consulta de esta obra, en la cual el autor es una autoridad para poder conocer, sirviendo de guía, e introducirse en tantos libros y autores de la Compañía de Jesús sobre el «ayudar a bien morir».

9 Juan de Polanco, Methodvs ad eos adivvandos, qvi morivntur, Romae, apud Victorium Aelianum, 1577.

Hispania Sacra, LXI

124, julio-diciembre 2009, 513-544, ISSN: 0018-215-X 
transcurso de la vida, pues al hacerla cotidiana se eliminaba su carácter terrible. Medios para alcanzar este objetivo era la continuada contemplación de la Pasión y Muerte de Cristo, así como la concepción de la muerte como descanso y coronación de todos los trabajos realizados en esta vida. Lo que debía producir auténtico temor era vivir en pecado. Quien ensayaba la muerte, después poco le costaría afrontarla, sirviendo esto para controlar además las pasiones naturales.

La bonanza de la vida futura se definía por tres puntos. En primer lugar, no poniendo el corazón en las cosas materiales pues siempre se habría de producir la separación de ellas. Debía ser considerada la vida terrena como un destierro, mientras que la futura y eterna se convertía en el estado natural del alma. Esa consideración de destierro se manifestaba numerosas veces cuando se describían las muertes virtuosas: «Nuestro Padre Ignacio, cargado ya de años [...] començó a pedir al Señor que fuesse seruido sacarle deste destierro y lleuarle á aquel lugar de descanso, donde con la libertad que desseaua pudiesse alabarle, y gozar de su bienaventurada presencia entre sus escogidos [...] tenía vn desseo tan encendido de ver á Dios y gozar del, que no podía de puro gozo pensar sin lágrimas en su tránsito» ${ }^{10}$. Escenas que se repetían habitualmente en las hagiografías.

\section{La ansiada buena muerte}

Aprender a morir, significaba aprender a vivir adecuadamente ${ }^{11}$. Para ello, la didáctica del discurso sabía poner ejemplos para conducir hacia una conversión de vida. Las hagiografías barrocas y sus iconografías pictóricas y escultóricas ratificaron ese cambio de prioridades del duque de Gandía, convertido en el padre Francisco de Borja ${ }^{12}$. Era aquella escena, en la cual, el fiel servidor de los

\footnotetext{
${ }^{10}$ Pedro de Ribadeneira, Vida del P. Ignacio de Loyola, fundador de la religión de la Compañía de Jesús, Madrid, Pedro Madrigal, 1594, pp. 251-252.

${ }^{11}$ La bibliografía acerca de la muerte, especialmente la barroca, es amplísima y ha contado a finales de los ochenta y en los noventa con un notable desarrollo. Carlos Álvarez SANTALÓ, «La Muerte Santa con Largo Exordio. Un ejemplo Gótico aderezado en el Barroco», en Estudios al Profesor Teófanes Egido, Valladolid, 2004, vol. II, pp. 139-151. Máximo GARCía FernándeZ, Los castellanos y la muerte: religiosidad y comportamientos colectivos en el Antiguo Régimen, Valladolid, Junta de Castilla y León, 1996. David GonZÁlez CRUz, Religiosidad y ritual de la muerte en la Huelva del siglo de la Ilustración, Huelva, 1993. Domingo GonZÁlez Lopo, Los comportamientos religiosos en la Galicia del Barroco, Santiago, 2002. Idem, «La vivencia de la muerte en las ciudades del Antiguo Régimen: Santiago en los siglos XVII al XIX», en La Ciudad y el Mundo Urbano en la Historia de Galicia, Santiago, 1988, pp. 179 y ss. Francisco J. LoRENZo PINAR, Muerte y Ritual en la Edad Moderna. El caso de Zamora (1500-1800), Salamanca, 1991. Fernando MARTínez GIL, Muerte y Sociedad en la España de los Austrias, Madrid, 1991, 2 tomos. Ofelia REY CASTELAO, «Evolución y resultados de los estudios sobre mentalidad y cultura en la Galicia del periodo moderno», Hispania, 176 (1990), pp. 1237-1258.

12 Enrique García Hernán, Francisco de Borja, Grande de España, Valencia, Diputación Provincial Valencia, 1999.
} 
emperadores acompañaba por las tierras de Castilla, camino de Granada, los restos mortales de la bellísima Isabel de Portugal que había retratado Tiziano; restos que se vio obligado a reconocer y en ver a qué había ido a parar aquella belleza presentada como transitoria ${ }^{13}$. Francisco Arana, en su obra «Muerte prevenida, cristiana preparación para una buena muerte» (Sevilla, 1736), describía la efectividad de aquella escena: «que toda carne es heno y toda su gloria como frágil flor de los prados, a la mañana hermosa y a la tarde marchita [...] que la mayor hermosura con la muerte se convierte en fealdad, asco y horror [...] A estas voces de la muerte en aquel su Real y mudado despojo se determinó el santo a dejar el mundo, a despojarse de toda su grandeza [...] a despreciar sus estados y riquezas, a morir al mundo y a vivir a sólo Cristo en el estado de la evangélica pobreza» ${ }^{14}$. La escena en la vida de Borja, como digo, era una verdad necesaria. En el caso de que no se hubiese producido, habría que haberla creado literariamente, pues iba a contar con la suficiente fuerza didáctica. Después sus iconografías iban a reproducirla en tantos lugares, llevando san Francisco de Borja, siempre en sus manos, la calavera coronada de las glorias y bellezas humanas. Conciencia, por parte del hombre, de sentirse mortal, efímero, no cayendo desde este sentimiento en la desesperación.

Los trabajos de los jesuitas en «ayudar a bien morir» se distinguían por la prudencia y el trato cordial que debían manifestar con el que agonizaba, aunque el padre Jerónimo Nadal pedía también paciencia y firmeza. Un sacerdote prudente tenía que convertirse, como escribía el jesuita de origen converso, Gaspar de Loarte ${ }^{15}$, en fuente de consuelo. Habrían de desarrollar una pastoral, dirigida hacia seres humanos vulnerables como eran los enfermos y los condenados a muerte y, por tanto, no podía ser dura e implacable. Más bien, era menester animar frente a las continuadas cargas presentadas para el transcurso de una vida

13 «Llegaron à Granada, y al tiempo de hazer la entrega del cuerpo de la Emperatriz, desataparon la caxa de plomo en que yua, y descubrieron su rostro: el qual estaua tan feo y desfigurado, que ponía horror à los que le mirauan; y no auía ninguno de los que antes la auían conocido, que pudiesse afirmar que aquella era la figura y cara de la Emperatriz. Antes el Marques de Llombay auiendo de consignar y entregar el cuerpo, y hazer el juramento en forma delante de testigos, y escribano, que aquel era el cuerpo de la Emperatriz, por verle tan trocado y afeado, no se atreuió a jurarlo. Lo que juró fue, que según la diligencia y cuidado que se auia puesto en traer y guardar cuerpo de la Emperatriz, tenía por cierto que era aquel, y que no podía ser otro [...] Y cotejando lo passado con lo presente, dezía en su corazón: Donde está, sacra Magestad, el resplandor y alegria de vuestro rostro? Donde aquella gracia y belleza tan estremada? Vos soys aquella doña Isabel? Vos soys mi Emperatriz y mi señora?», en Pedro de Ribadeneyra, Vida del Padre Francisco de Boria, que fve dvque de Gandia, y después Religioso, y tercero General de la Compañía de Iesus, dirigida al Catolico Rey don Felipe II, nuestro Señor, Madrid, por Pedro Madrigal, 1594, pp. 25 y ss.

14 Francisco ARANA, Muerte prevenida, cristiana preparación para una buena muerte, Sevilla, 1736, ff. 344 y ss.

${ }^{15}$ Gaspar de LoARTe, Avisi di Sacerdoti et Confessori, composti per il R.P..., Dottor Theologo della Compagnia di Giesu, Parma, Erasmo Viotti, 1584.

Hispania Sacra, LXI

124, julio-diciembre 2009, 513-544, ISSN: 0018-215-X 
cristiana virtuosa. Una visión tan prudente que parecía no compartir el jesuita Juan Bautista Poza cuando escribía sobre el origen de la enfermedad. Afirmaba que aquel se encontraba en el pecado mismo, siendo imposible que los médicos pudiesen superarla: «efecto es de la divina clemencia, que no acierten los médicos, que ignoren la naturaleza y circunstancias de la dolencia, que apliquen fuera de tiempo los medicamentos, que los den trocados o viciados en la botica, que no se acierte o yerre la sangría, que finalmente en todo se alucine: porque ésta es herencia de nuestra naturaleza, según el Eclesiástico» ${ }^{16}$. La forma de combatir el mal era a través de la penitencia y la confesión, la oración, las limosnas, la intercesión de los santos, pidiendo a Dios -según el padre Poza- que recortase la vida al moribundo para tener menos posibilidades de morir en pecado, algo que parecía oponerse al consuelo que se pretendía dar a los enfermos. Precisamente, ese concepto pecaminoso del hombre, hacía más presente al demonio, materializado en las tentaciones que podían presentarse al enfermo, especialmente, la desconfianza en la salvación. Los directores espirituales ponían énfasis en cuidarse de los demonios que atacaban en el instante de debilidad, aunque de frente se hallase el bien.

La Compañía de Jesús se había convertido en maestra de la dirección espiritual, la cual debía ser distinguida de la confesión o en la aplicación del sacramento de la penitencia, tan impulsado con el Concilio de Trento ${ }^{17}$. Naturalmente, los jesuitas no fueron sus inventores, ni tampoco los únicos que practicaron la dirección espiritual, aunque la desarrollaron con auténtica efectividad. Un director espiritual se debía también al enfermo agonizante en los últimos momentos de su vida. El aumento rápido de la credibilidad y prestigio de los jesuitas condujo a que muchos de estos religiosos fuesen requeridos a los pies de la cama del enfermo. Así lo indicaban los primeros jesuitas que vivieron en Valladolid ${ }^{18}$ : «nos llaman muy a menudo a confesar enfermos por el pueblo y ayudar a morir» ${ }^{19}$. Por algo -según había escrito Polanco- era más necesario ayudar a bien morir que a bien vivir. Un director espiritual tenía que utilizar un estilo llano, claro, afectuoso, sin dar sensación alguna de prisa.

\footnotetext{
16 Juan Bautista PozA, Práctica de ayudar a bien morir. Ahora nuevamente añadidos muchos ejemplos de santos, Barcelona, imprenta de Sebastián de Cormellas, 1647, f. 54v.

17 Jean Delumeau, La Confesión y el Perdón. Las dificultades de la confesión. Siglo XII al XVIII, Madrid, 1992.

18 «Carta de Juan de Valderrábano a Ignacio de Loyola», Valladolid 22 enero 1552, Monumenta Historica Societatis Iesu (en adelante MHSI), Litterae Quadrimestres ex universis praeter Indiam et Brasiliam locis in quibus aliqui de Societate Iesu versabantur, Matriti, Augustinus Avrialc, 1894, vol. I, p. 525. vid. Javier BURRIEZA SÁnchEZ, Valladolid, tierras y caminos de jesuitas, Valladolid, Diputación Provincial, 2007.

19 «Carta de Pedro Doménech a Diego de Laínez», Valladolid 26 marzo 1557, MHSI, Litterae Quadrimestres..., ob. cit., Matriti, Augustinus Avrialc, 1894-1932, vol. V, pp. 142-143.
} 
El que era ayudado a bien morir, como ocurría con otros ministerios, no iba a ser el único beneficiado en el proceso, sino también el que auxiliaba espiritualmente, pues ello contribuía a su perfeccionamiento. Además, ayudar a bien morir formaba parte del proceso formativo de un jesuita, siendo enviados los escolares a estas tareas, es decir, los que habiendo superado el periodo de probación o noviciado ya se estaban formando en las materias propias de la filosofía y la teología ${ }^{20}$.

Ayudar a bien morir consistía en una plática espiritual, debiéndose adaptar la duración y el contenido a la persona a la que se dirigiese. El jesuita tenía que respetar las competencias parroquiales, que le solía administrar los sacramentos del viático y extremaunción. El religioso de la Compañía ponía mucho hincapié en preparar al moribundo para recibir adecuadamente la confesión y la comunión. Los sacramentos podían ser los que transformaban el temor en un «puro amor a Dios nuestro Señor». Con los moribundos, la confesión se convertía en algo más que en un sacramento, acercándose más al ámbito de la dirección. El padre Jerónimo Nadal, incluso, lo definía como una «conversación espiritual» ${ }^{21}$. Los jesuitas habían llamado constantemente en vida a la frecuencia sacramental, lo que suponía una interrelación entre confesión y comunión. Juan de Polanco destacaba por el carácter práctico de sus instrucciones cuando advertía que había que llegar antes de la pérdida de entendimiento del enfermo. Entonces, el sacerdote tenía que buscar el momento en el que se podía hallar la señal más mínima de arrepentimiento. Era menester tener, también, en cuenta a los que eran más persistentes, buscando los medios y autoridades oportunas para convencerlos de su error. En casos extremos, Polanco llamaba a la lectura del libro del Eclesiástico, donde se resaltaba el juicio implacable de Dios, así como el recuerdo de la inminencia de la muerte.

El objetivo era la absolución de los pecados, buscando la necesidad de confesar su fe en la Iglesia. Ahí, se incluye la preocupación por el arrepentimiento sincero de todos sus pecados, llegando de la atrición hasta una contrición perfecta $^{22}$. Los jesuitas se habían distinguido por una práctica penitencial benévola, pues consideraban que lo importante era que el pecador se acercase para arrepentirse. De allí, nacieron las acusaciones de laxismo hacia la Compañía y sus confesores. Aquel deseo de llevar al penitente al confesionario evolucionó, en la segunda mitad del XVII, hacia un mayor rigorismo moral. Si un confesor benévolo era una atracción para una vida cristiana más cercana y posible, tam-

\footnotetext{
20 «Como en lo dicho se ayudan los próximos a bien vivir, assí es de procurar de entender lo que ayuda a bien morir, y el modo que se ha de tener en puncto tan importante para conseguir o perder el último fin de la felicidad eterna», Constituciones, parte IV, cap. $8^{\circ}, 412$, en Obras de San Ignacio de Loyola..., ob. cit., p. 551.

${ }^{21}$ John O’MALLEY, Los primeros jesuitas, Bilbao, Sal Terrae, 1993, pp. 218-223.

22 Jean Delumeau, ob. cit.
} 
bién había de buscar un adecuado maestro para la buena muerte. La dilatación de la absolución en una persona en peligro de muerte podía ser trascendental para su «destino» eterno. Así, a través de la última confesión, la muerte con esa actitud de consuelo del confesor, se convertía en una oportunidad de reconciliarse con Dios ${ }^{23}$.

Una vez transcurrido la dimensión sacramental, el jesuita podía volver para permanecer junto al agonizante en los últimos momentos de su vida. Juan Eusebio Nieremberg, en su confianza en la misericordia infinita de Dios, llamaba a la invocación de los santos y de la Virgen, además de la utilización del agua bendita ${ }^{24}$. Pide al enfermo, en este caso, obediencia con el médico y resignación para la aceptación de la voluntad de Dios. Hacía una llamada de atención a las visitas, no siendo éstas en ocasiones lo más edificativo para la actitud del moribundo.

Todos los tratadistas de la buena muerte consideraban que la contemplación de la Pasión de Cristo servía para el auxilio del moribundo. Éste tenía que asociar sus padecimientos a los de Jesús en la cruz, pues participando en su muerte, lo haría también de su resurrección. El tiempo último de la agonía, según sugiere Nieremberg, habría de ser con un crucifijo en las manos. Con el agua bendita se rociaba al enfermo, mientras que la candela encendida tenía que ser portada en la mano. A todo ello acudían, no solamente un jesuita, sino un equipo de dos, más conocido como «bina», compuesto por un sacerdote y un hermano, «equipos» organizados y repartidos por cada uno de los rectores de los colegios; reparto que podía cambiar diariamente con cada uno de los turnos.

\section{Diversidad de muertes, diversidad de trabajos}

No todos los trabajos de los jesuitas que atendían a los moribundos, contaron con la misma repercusión que Jerónimo de Florencia, cuando acudió a los últimos momentos del rey Felipe III ${ }^{25}$. Desde las exequias de Margarita de Aus-

\footnotetext{
23 J. O’MALley, ob. cit., p. 221.

24 Juan Eusebio Nieremberg, Partida a la eternidad y preparación para la muerte [...] A D. Miguel Bautista de Lanuza, Regidor y Administrador Perpetuo del Hospital Real y General de N. Señora de Gracia de la Ciudad de Zaragoza, Zaragoza, Pedro Verges, 1643; Idem, Diferencia entre lo temporal y eterno: crisol de desengaño, con la memoria de la Eternidad: Postrimerias Humanas y principales Mysterios Divinos, Madrid, Manuel Fernández, 1735.

25 Jvan de Montalvo, De la vida y muerte del padre Jerónimo de Florencia, Archivum Romanum Societatis Iesu (en adelante ARSI), Tolet, 45. Fidel FITA, Galería de jesuitas ilustres, Madrid, 1880, pp. 65-92; H. D. SMith, Preaching in the spanish Golden Age. A Study of some Preachers of the Reign of Philip III, Oxford, 1978; M. SÁncheZ, The Empress, the Queen and the Nun. Women and Power at the Court pf Philip III, Baltimore y Londres, The John Hopkins University Press, 1998.
} 
tria, el padre Florencia se había distinguido en su oposición al valido el duque de Lerma, reconociendo el propio monarca que gracias a los sermones de este jesuita había encontrado la razón para prescindir de los favores de Francisco Gómez de Sandoval y Rojas en $1618^{26}$. Lo cierto, es que el afamado predicador fue llamado junto al lecho del monarca agonizante que mostraba su preocupación por el buen gobierno, la honra de los que eran buenos y el castigo de los «bellacos». El papel que adquirió el jesuita en estos momentos fue en detrimento del que había sido confesor del rey, el dominico fray Luis de Aliaga, acusándole Felipe III de la mala dirección de su alma. Florencia, sin embargo, se convirtió en el bálsamo tranquilizador para un rey atormentado: «iOh, si Dios me diese vida -decía- quán diferentemente gobernara!». Jerónimo de Florencia fue bien recibido por el heredero Felipe IV y el jesuita se mostró públicamente partidario de Gaspar de Guzmán, entonces conde de Olivares ${ }^{27}$.

Aunque los ministerios de los jesuitas debían ser gratuitos y por las Constituciones, según veremos después, no tenían que mezclarse los religiosos en los asuntos propios de los testamentos, algunas veces esta asistencia a la hora de la muerte se mostraba altamente rentable. Después de que el obispo de Plasencia, Gutierre Vargas de Carvajal llamase junto a su lecho al padre Pedro de Saavedra, director espiritual de otros ilustres en aquel mediar del siglo XVI, el prelado realizó una importante donación al colegio de la Compañía en la capital de su diócesis. Una voluntad que valía dos mil ducados de renta anual. Se decía que los jesuitas le habían convertido en un obispo de acuerdo a las exigencias del Concilio y, cómo escribía Francisco de Borja a su muerte en la villa de Jaraicejo, «[Gutierre de Vargas] pedía siempre a los padres [de la Compañía] que con él estaban que le ayudasen a bien morir [...] A mí me da Nuestro Señor que le tiene en el número de los escogidos». A pesar de la conversión impulsada por los jesuitas, éstos no habían conseguido restituir las relaciones cordiales con el Cabildo de su Catedral de Plasencia, habitual foco de conflictos con un obispo ${ }^{28}$.

En las Constituciones de la Compañía, en su parte VI (capítulo $\left.4^{\circ}\right)^{29}$, se especificaba «la ayuda que se da en la muerte de los de la Compañía y sufragios

\footnotetext{
${ }^{26}$ Fernando Negredo DEl CERRo, Los predicadores de Felipe IV. Corte, intrigas y religión en la España del Siglo de Oro, Madrid, editorial Actas, 2006; Félix Herrero SAlgado, La oratoria sagrada en los siglos XVI y XVII. La predicación en la Compañía de Jesús, Madrid, Fundación Universitaria Española, 2001.

27 Julián J. Lozano Navarro, La Compañía de Jesús y el poder en la España de los Austrias, Madrid, editorial Cátedra, 2005.

${ }^{28} \mathrm{Cfr}$. XXXV Coloquios Históricos de Extremadura: dedicado a la memoria del obispo D. Gutierre de Vargas Carvajal, celebrados en Trujillo, entre el 18 y el 24 de septiembre de 2006: Coloquios Históricos de Extremadura $(35,2006)$.

29 «De la ayuda que se da en la muerte de los de la Compañía y sugrafios después della», en Constituciones, parte VI, cap. $4^{\circ}$, 595-600, Obras de San Ignacio..., ob. cit., pp. 590-591.
} 
después della». El acompañamiento no era sólo a través de la oración, pues todos los miembros de la casa podían y debían entrar a ver morir al que se hallaba en la última enfermedad, aunque unos pocos fuesen los que le cuidasen. La oración era anterior y posterior al fallecimiento, celebrando los sacerdotes de la Compañía sufragios por su alma y anunciándolo allá donde se pudiese llegar. La muerte de un religioso se convertía en manifestación de la gloria de Dios. En la Compañía, en la que todo se hallaba reglamentado y no se dejaba nada a la improvisación, cada uno de los miembros del Instituto era enterrado de una manera, dependiendo si era hermano, escolar o sacerdote, aunque se tendió a uniformar los usos y costumbres.

La muerte de un jesuita siempre era resaltada en las cartas de edificación, con mayor publicidad para aquellos religiosos que hubiesen gozado de fama de santidad ${ }^{30}$. La vida de un jesuita «virtuoso», una vez desaparecido, se convertía en atractiva para su imitación. Al principio, las defunciones eran anunciadas por las cartas annuas enviadas a Roma. Los más ilustres y conocidos contaban con sermones que habían sido primero pronunciados en sus honras fúnebres y después eran entregadas a la imprenta. Las mismas directrices que los jesuitas tomaban con muchos de sus clientelas espirituales, la ejercían con los suyos, en cuyos finales no estaba ausente lo sobrenatural. Juan Eusebio Nieremberg culminaba «su» Vida del padre Martín Gutiérrez, el prepósito o superior de la Casa Profesa de Valladolid, con un relato sobre la disposición de su muerte. Había fallecido en el presidio, cuando tanto él como Juan Suárez y Gil González Dávila, se dirigían caminando por tierras de hugonotes hacia Roma, donde habría de celebrarse Congregación General que eligiese al sucesor de Francisco de Borja tras su muerte. Los tres jesuitas fueron encarcelados pero tras la muerte del padre Gutiérrez, una mujer cuya procedencia se desconocía -«vna muger con hábito de Francesa»- acudió a amortajarle: «todos entendieron -concluye Nieremberg recogiendo tradiciones de los antiguos padres- que esta muger era nuestra Señora o persona embiada por ella, para remediar el aprieto de sus siervos viuos y la necesidad de su sieruo difunto» ${ }^{31}$.

\footnotetext{
${ }^{30}$ El Archivo del Colegio Inglés de San Jorge de Madrid, depositado actualmente en el Archivo del Colegio de San Albano de Valladolid (ACSA), posee una importante colección de Cartas edificantes manuscritas de jesuitas, pertenecientes a la provincia de la Compañía de Jesús de Toledo, cfr. Madrid. Cartas edificantes, 1678-1709, vol. III; Madrid. Cartas edificantes, 1709-1766, vol. IV. Asimismo, las procedentes del Colegio Inglés de San Gregorio de Sevilla, también depositadas en el mencionado Archivo Colegio de San Albano (ACSA). Pertenecían a padres y hermanos de la provincia jesuítica de Andalucía, cfr. ACSA, Legs. 012 (012.1), 013 (013.1).

31 Juan Eusebio NiEREMBERG, Firmamento religioso de lvzidos astros, en algvnos Claros Varones de la Compañía de Jesvs, cumplense en este tomo y en el antecedente vna centuria entera por... al excelentísimo señor don Gaspar Hurtado de Mendoça Moscoso Ossorio y Córdoua, Marqués de Almaçán, Madrid, por María de Quiñones, 1644, vol. II, p. 67.
} 
Los jesuitas gustaban de encontrarse cercanos de aquellos que eran considerados como santos en esa sociedad sacralizada en la que vivían. Las hagiografías, de las que en ocasiones eran autores, hablaban de que el santo se percataba perfectamente de que estaba llegando el final de su vida. La predicción de la muerte era una revelación muy habitual en todos aquéllos que contaban con fama y olor de santidad. El padre Miguel de Oreña, rector del colegio de San Ambrosio de Valladolid, fue minucioso en su testimonio cuando se dirigió al conde duque de Olivares poco días después de la muerte de Marina de Escobar $^{32}$, hija espiritual de los jesuitas. Por una parte, la salvación parecía asegurada, pues así se lo había mantenido muchos años antes el que había sido su confesor más importante, Luis de La Puente. Incluso, Marina de Escobar había tenido revelaciones sobre la salvación de otras personas que había conocido ${ }^{33}$. Si esta vallisoletana había nacido al principio de una Cuaresma, su muerte comenzó a llegar al final de una Pascua, en la festividad del Corpus Christi:

«El Iueues día de la Solemnidad del Corpus, fui á confessarla, y a dezirla Missa a las quatro y media de la mañana, como lo hazía otros días, y dándome quenta, me dixo, que dos horas antes, poco más ó menos auía visto en su aposento al demonio haziendo representación de la Persona de Iesu Christo Señor nuestro; pero que ella le auía conocido luego: y que en el mismo instante vno de aquellos Santos Ángeles, que siempre la asistían, auía acudido, y dándole muchos golpes con vn látigo le auía echado de allí. Y añadió, temo que me ha hecho algún daño, y arrojándome algún veneno: porque luego se llegó a mi el Santo Ángel de mi guarda, y me traxo la mano por la frente, y por la cabeça, como alagándome y aplicándome alguna medecina. Poco después vio baxar del Cielo a Iesu Christo Señor nuestro rodeado de muchos Ángeles, que estuuo con ella consolándola, y alentándola, y la comulgó espiritualmente. Esto y otras cosas, que passaron, me refirió

\footnotetext{
32 Andrés Pinto RamíreZ, Segunda parte. Vida Maravillosa de la Venerable Virgen Doña Marina de Escobar, natural de Valladolid, sacada de lo que ella misma escribió, de orden de sus Padres Espirituales y de lo que sucedió en su muerte. Escrita por el Padre..., de la Compañía de Jesús, que fue de Sacra Scriptura en el Colegio Real de Salamanca de la misma Compañía, Madrid, Francisco Nieto, 1665; María Antonia FERnÁNDEZ DE HoYo, «Marina de Escobar», Vallisoletanos, Valladolid, Caja de Ahorros Popular, 1983; Javier BuRrieZA SÁncheZ, Los Milagros de la Corte, Valladolid, Real Colegio de Ingleses, 2002.

33 «Para consuelo de los que aora viuimos, haré vn breve catlogo de algunas personas seglares, y Religiosas que vio en el Cielo, y algunas dellas vinieron a verla. Vio a la Sereníssima Reyna Doña Margarita de Austria, muger del Rey Don Felipe Tercero, grande Madre, y Protectora de nuestra Compañía, cuya vida tan deuota, y ejemplar asegura la verdad desta reuelacion. La Duquesa de Alba Doña María de Toledo, Fundadora del Monasterio de la Laura, y mostraua tener grande gloria, por la grandeza de sus obras. Al Obispo de Valladolid Don Francisco Sobrino que la confessó muchas vezes y atestiguó la verdad de la Purísima Concepción de nuestra Señora. Al Doctor Méndez de Puebla, Oydor en esta Real Chancillería, Varón de insigne piedad, y por estremo aficionado a esta sierua de Dios, y a este modo vio otros del estado seglar, que dexo. Tambien vio a muchos insignes Varones de la Compañía, que la auían tratado aquí en Valladolid», en Luis de LA Puente, Vida Maravillosa de la Venerable Virgen Doña Marina de Escobar natural de Valladolid, sacada de lo que ella misma escriuio de orden de sus Padres Espirituales, Madrid, por Francisco Nieto, 1665, p. 438.
}

Hispania Sacra, LXI

124, julio-diciembre 2009, 513-544, ISSN: 0018-215-X 
muy de espacio, y yo dixe Missa y la Comulgué [...] y los médicos y yo que la asistía con las de casa, echáuamos de ver que no podían proceder aquellos efectos de causa humana [...] Con estos tormentos tan rigurosos se fue estenuando la naturaleza, de suerte que juzgaron los Médicos que era conueniente darle el Santíssimo Sacramento por Viático [...] Preguntauale algunas vezes como le iba en lo interior del alma? Y respondíame. Padre con grandes escuridades y desamparo me tiene nuestro Señor [...] passó assí hasta el lunes antes de su muerte, que a la vna de la noche me dixo, que la parecía, que sería bueno que la diessen la extremavnción, embiamos por ella, y recibióla, sossegándose entonces por vn breue rato, y boluiendo luego los dolores con la misma furia [...] durando hasta el Miércoles a las nueue y media de la noche, en que cessaron todos, y pude hablarla algunas palabras, pero pocas: porque luego començó á suspenderse en vn rapto espiritual, que duró desde aquella hora hasta el Iueues poco antes de la diez del día [...] que fue nueue de Iunio [...] y es conforme a otras (revelaciones) que ella también tuuo de nuestro Padre San Ignacio, y de otros Santos Patriarcas, que la dixeron que en su tránsito se hallarían presentes con muchos ángeles, y almas bienauenturadas, y la lleuarían consigo a la Celestial Ierusalén, donde tuuiesse por toda la eternidad la possesión de aquellos bienes, de que el Señor tantas vezes la auía enseñado alguna partecica» ${ }^{34}$.

Un santo, a menudo no tenía una vida fácil, pues su existencia frecuentemente era corta y se interrumpía en plena juventud. Ésta no era un obstáculo para alcanzar la santidad. Los jesuitas ponían un ejemplo muy claro, además de práctico para el proceso de formación del religioso: Estanislao de Kostka, modelo para la juventud cristiana. La razón es que en él, la juventud se había convertido en madurez: «admirable por lo grande de su vida en tan corta duración -escribía el jesuita académico José Cassani-, pues veremos en diez y ocho años solos de edad, la cana madurez y consumada virtud, que pudiera ser admiración después de muchos lustros» ${ }^{35}$.

Existía una prevención hacia las muertes inesperadas y solitarias. La propia de Ignacio de Loyola tuvo esa segunda consideración. En aquel mes de julio de 1556 los que le rodeaban no se percataron de su gravedad, salvo el padre Diego de Eguía (que también murió aquel año) cuando escribió que el prepósito general vivía de milagro. El que previsiblemente iba a sucederle, Diego de Laínez, también contaba con una salud muy deteriorada. Cuando el 29 de julio de 1556, Ignacio mandó llamar al médico lo hizo pensando más en su sucesor que en él mismo. Por eso, pidió a su secretario que volase hacia el Papa para solicitarle la

34 «Copia de vna carta, que el Padre Miguel de Oreña, Rector del Colegio de la Compañía de Iesús de San Ambrosio de Valladolid, escriuió al Excelentísimo Señor Conde Duque, de la muerte de la Señora Doña Marina de Escobar, cuyo Confessor era», en Andrés PINTO RAMíREZ, Segunda parte. Vida Maravillosa..., ob cit, pp. 453-456.

35 José CASSAni, Vida y virtudes de San Stanislao de Kostka de la Compañía de Jesús, de quien nuestro Santo Padre Clemente Undezimo ha despachado Breve para que se proceda a la función de canonización. Su autor P..., de la misma Compañía, académico de la Academia Real Española, Madrid, Gabriel del Barrio, 1715, pp. 3-4. 
bendición tanto para él como para Laínez. Paulo IV, entonces, se encontraba en guerra con Felipe II. Sin embargo, para el general de la Compañía por encima de todo era el Papa, cabeza visible de la Iglesia. Una vez más, ante aquel enfermo eterno, Polanco pensó que su superior exageraba sus dolencias y aunque insistía, el eficaz secretario pensó que era más urgente despachar el correo que al día siguiente debía salir para las provincias de España. Cuando la noche se despedía y comenzaba a amanecer sobre Roma, los jesuitas encontraron que Ignacio de Loyola se estaba muriendo. Fue entonces cuando Polanco salió aprisa hacia el Vaticano. Pero cuando volvió a su casa de Santa María della Strada, su superior había muerto. Lo hizo en soledad, sin palabras a los que le rodeaban, sin sacramento, ni bendiciones. Era la madrugada del 31 de julio ${ }^{36}$.

En esa misma línea de muertes solitarias se hallaban también las repentinas de soldados o marinos, de las que se preocupó en su manual de la buena muerte el cardenal jesuita Roberto Bellarmino ${ }^{37}$. Sin duda, su planteamiento es moderno cuando afirma que los militares no debían participar en aquellas guerras en las que no tuviesen la seguridad de que no fuesen justas. Si lo tenían que hacer por obediencia a su príncipe, al menos debían ser conscientes que era una guerra injusta. Les advertía de que no cometiesen pecados graves en su condición de soldados. Si una persona moría violentamente «por justicia» y lo hacía conforme a la voluntad de Dios, alcanzaba satisfacción después de realizada la debida penitencia. Los que mueren injustamente y han perdonado sinceramente a los que han propiciado su muerte, ésta alcanzaba una dimensión redentora para sus perseguidores. El mayor problema era que la muerte podía sorprender a una persona de improviso, careciendo del tiempo para prepararse. Hacia una llamada Bellarmino a la previsión, ilustrando todo ello a través de textos del Evangelio cuando recordaba la parábola de las doncellas necias y las diligentes, que tenían preparadas sus lámparas con la reserva de aceite que era menester.

Precisamente, relacionado con esa dimensión redentora de la muerte, se hallaba la propia de un mártir, palabra que etimológicamente significa «testigo», pero al mismo tiempo se presentaba como legitimador de una causa, con independencia de la orilla en la que se encontrase. Así lo plasmaron en el siglo XVI tanto los protestantes, los anglicanos como los católicos, siendo los segundos - por ejemplo, en Inglaterra- más prestos a hacer las recopilaciones de sus finales. El deber de los católicos, escribía el padre Alonso de Andrade en sus libros de «Varones Ilustres» de la Compañía de Jesús, era distinguir a los que habían

\footnotetext{
36 Pedro de Ribadeneyra, Vida del P. Ignacio de Loyola, fundador de la religión de la Compañía de Jesús, Madrid, por Pedro Madrigal, 1594, p. 252.

${ }^{37}$ Roberto Bellarmino, El arte de bien morir. En dos libros por el eminentísimo Sr. Cardenal de la Santa Iglesia de Roma de la Compañía de Jesús [...] Traducidos del latín en castellano por el Doctor Lucas de Soria, Presbítero de la Santa Iglesia de Sevilla, consultor de la Inquisición, Sevilla, 1640.
}

Hispania Sacra, LXI

124, julio-diciembre 2009, 513-544, ISSN: 0018-215-X 
destacado en la defensa de la fe. Los mártires, ejemplos de muerte heroica para aquellas mentalidades, eran aquella «armada de un esquadrón de tan lucidos y tan invencibles soldados», según escribía Pedro de Ribadeneira ${ }^{38}$. Después del Concilio de Trento, y en plena expansión misional católica, los escenarios de los martirios se ampliaron: los nuevos mártires de Japón, China, India o Inglaterra eran presentados como manifestación de Dios y de sus obras. Y así lo entendieron las hagiografías de la Compañía desde el principio, desde la muerte del primero de ellos en estos trabajos, el italiano Antonio Criminal, en tierras de la misión de Oriente.

Las vidas de los mártires, todas ellas tan atrayentes con su final incluido, despertaban «deseos ardientes de imitación». Gentes dirigidas por los jesuitas o empapadas por su espiritualidad, conocedoras del final de jesuitas como Edmund Campion en la Inglaterra isabelina, mostraban sus ansias por convertirse en mártires. El caso más paradigmático es el de Luisa de Carvajal, muy próxima a las noticias de los católicos ingleses pues en España se recibían por conducto de Bernardino de Mendoza, embajador español ante Isabel I. Ya en 1598 había formulado voto de martirio, en el que manifestaba su ansiedad por participar como víctima en la persecución de la que eran objeto los católicos ingleses tras la consolidación del anglicanismo. Todo ello se intensificó cuando empezó a ser vecina del colegio de ingleses de Valladolid y sobre todo cuando vivió muy de cerca el final del también jesuita Henry Walpole, destacado entre otros por sus hermanos, también jesuitas y moradores de estos colegios. Todos ellos se enfrentaban a un cambio de rumbo en la política internacional que no entendieron. Nos referimos a la Paz de Londres de 1604. La heroicidad del mártir, y esto es lo que nos interesa para la muerte, se apreciaba en sus trabajos desarrollados en la clandestinidad; sus victorias en controversias y debates, según transmitían los Menologios ${ }^{39}$.

«En este año el padre Thomas Garnet, antiguo alumno de este colegio donde había partido hacia la misión inglesa en el año de la salvación de 1599 [...] cayó en manos de los que estaban acechándole. Durante algunos meses sufrió la reclusión y la miseria de la cárcel hasta que, por fin, fue llevado a juicio. Sobre él pesaba un doble cargo que adelantó su martirio. Primero había entrado en la Compañía de Jesús, pues unos años antes de abandonar Inglaterra para ir a Lovaina había realizado su preparación preliminar en la Compañía. En segundo lugar su tío era Henry Garnet. El padre Garnet, después de haber sido el responsable de la Compañía durante mucho tiempo en Inglaterra, fue finalmente capturado en el año 1605, y al año siguiente, el tres de mayo, en Londres, lo sentenciaron a la pena máxima. Porque conocía el complot de la pólvora, ya que se lo habían revelado bajo secreto de confesión, y él no había informado al magistrado. Estos dos hechos no le

\footnotetext{
38 Pedro de Ribadeneyra, Flos sanctorum, 1599, t. I: «De los tormentos de los mártires».

${ }^{39}$ Menologio de los varones más señalados en perfección religiosa de la Provincia de la Compañía de Jesús de Nueva España, Barcelona, 1671.
} 
hacían merecedor de la compasión de malintencionados jueces, por lo que era seguro que tendría que sufrir el peor de los castigos. Cuando le acusaron de estos dos cargos, que era jesuita y familiar directo del famoso traidor Garnet, él dijo: «Pertenezco a la Compañía de Jesús, si bien es cierto que soy el más indigno siervo de la misma. Si eso es un delito, ante vosotros me declaro culpable y no deseo perdón. De la misma forma no me avergüenzo de mi tío, pues no ha hecho nada deshonroso, y aunque le acusasteis ante el pueblo proclamándolo el hombre más perverso del mundo, posteriormente el cielo y la tierra han dado testimonio de su inocencia».

Replicaron: «tú eras cómplice de sus secretos y estabas involucrado en el mismo infame episodio. ¿Qué argumento puedes exponer a tu favor para que no se te condene con la misma sentencia que a él?» «Si mantenéis esa sentencia» contestó el mártir «me castigáis de la misma forma, de acuerdo con el procedimiento rutinario. Es obvio para cualquier persona que no tenéis intención de absolverme, diga lo que diga, aunque me defienda con argumentos más claros que el agua. No os mueve la sospecha de este delito, para el que no sois capaces de presentar ninguna prueba que acredite la acusación, sino el odio por la religión que profeso. Si esto no es así, presentad un solo testigo, una sola conjetura que pruebe que soy culpable del delito del que se me acusa, y entonces no tendré caso que defender». Cuando se dieron cuenta de que las amenazas que lanzaban contra él no iban a surtir ningún efecto, terminaron por instarle para que pudiera exonerarse haciendo juramento de lo ordenado por el rey y el reino para probar la fidelidad de los católicos al monarca. Como se negó en rotundo a hacer tal cosa, se dictó su sentencia de muerte y se lo llevaron del tribunal exultante de alegría.

Y al día siguiente, cuando lo sacaban para ejecutarlo, se encontró entre otros nobles al duque de Exeter, el hijo y heredero del gran Cecil y miembro del consejo del rey, que apartando al padre de la multitud allí congregada, se puso a hablar con él largo y tendido. No se conoce con certeza el asunto de la conversación, o bien le estaba intentando convencer para que hiciera el juramento o estaba tratando de sonsacarle algo. Pero en cuanto acabó esta entrevista el mártir fue conducido hasta los pies del patíbulo y despojado de sus ropas, para que después de ahorcarlo fuera más fácil descuartizarlo. Después de que hubo orado en silencio no le permitieron que se dirigiera a la multitud. Entonces se dispuso a seguir los mismos pasos que otros los mártires habían dado antes que él y cumplió con su deber con dignidad de una manera edificante y ejemplar» ${ }^{40}$.

El mártir se gozaba en los tormentos (siempre terribles, como se acentuaban) y con sus gestos parecían encontrarse por encima del sufrimiento, porque

40 The Blackfan Annals. Los Anales de Blackfan. Annales Collegii Anglorum Vallesoletanum, editado por Peter E.B. Harris, Valladolid, ACSA Series Volume I, Real Colegio de Ingleses, 2008, pp. 131134.

Hispania Sacra, LXI

124, julio-diciembre 2009, 513-544, ISSN: 0018-215-X 
sufrían en nombre de Dios. Sufrimiento que, según algunas relaciones, era acompañado con cantos de alabanza a Dios: «mientras ardía vivo -cuentan los Menologios para el jesuita calabrés Camilo de Constanzo, misionero en Japón-, le oyeron cantar con júbilo alabanzas al Señor» ${ }^{41}$. E incluso, en ocasiones, rechazaban la posibilidad de escapar e incluso la conmutación de la pena: «viuo le descuartizan, y él [Henry Walpole] gozoso», cantaba una de las octavas españolas colocadas a ambos lados del retrato de este jesuita mártir cuando en 1600 visitaron el colegio de ingleses Margarita de Austria y Felipe III ${ }^{42}$. Últimas palabras, las de los mártires, que siempre debían ser de perdón hacia sus verdugos.

La atención de los jesuitas a los presos en las cárceles, y muy especialmente a los que habían sido condenados a muerte, merece un estudio aparte, que se va realizando para diferentes ámbitos. En Valladolid, por ejemplo, puede cobrar este trabajo un interés particular por ser ésta una ciudad de diversas jurisdicciones. Esta atención al condenado se unía a unos trabajos más generalizados de enseñanza de la doctrina cristiana, es decir, del catecismo dentro de las cárceles. Los destinatarios de esto segundo solían ser presos que se encontraban privados de su libertad por haber cometido delitos materiales, mientras que los que esperaban su ejecución, esos sí, solían ser criminales ${ }^{43}$. Relataba el cronista de la Castilla jesuítica, Pedro de Guzmán, el poder de persuasión que caracterizaba al padre Francisco Morales: «Le hauía dado nuestro Señor particular gracia como se vio muchas veçes en hombres condenados a muerte por sus delictos que estando tan duros y obstinados, que parecían vnos demonios en carne humana por su medio les venía Dios a hablar y deshacer en lágrimas. No dejaré de contar aquí vna cosa graciosa y fue que estando subido vn condemnado en lo alto de la escalera para darle el traspie pidió atención y dijo al auditorio que quando algunos se viesen en aquel trance llamasen al padre Morales que le yría con él muy bien» ${ }^{44}$.

No solían estar presentes los jesuitas en las conmutaciones de penas, aunque el Chronicon que escribió el secretario Juan de Polanco mencionaba la suspensión de la pena capital para una mujer acusada de adulterio en Valladolid en

${ }^{41}$ Traslado del Menologio de Varones Ilustres de la Compañía de Jesús, Madrid, 1729: Camilo Constanzo, 15 septiembre, p. 117.

42 Antonio de OrTiz, Relación de la venida de los Reyes Cathólicos al Collegio inglés de Valladolid en el mes de agosto. Año de 1600. Y la colocación y fiesta hecha en el mesmo Collegio, de vna imagen de Nuestra Señora maltratada de los hereges, dirigida a la Sereníssima señora Infanta de España doña Isabel Clara Eugenia, Madrid, por Andrés Sánchez, 1600, p. 10.

43 J. O'MALLEY, Los primeros jesuitas..., ob. cit., p. 217.

${ }^{4}$ ARSI, Pedro de GuZmán, Historia de la Compañía de Jesús de la Provincia de Castilla la Vieja, Castellana 35-I, f. 105. Juan Eusebio NierEmBerg, Honor del gran patriarca San Ignacio de Loyola, Madrid, por María de Quiñones, 1645, vol. III, p. 449. 
1551 , en virtud de las negociaciones que efectuaron estos religiosos. Una asistencia a los condenados que se integraba en la realidad sacralizada del momento. Tanto en Florencia como en Roma habían nacido cofradías para consolar a los condenados a muerte, a la cual se habían ido asociando otras de similares funciones en ciudades diferentes del mundo católico. Se trataba de compartir los beneficios espirituales concedidos por los papas a la «prima primaria» de Roma. Los seglares -pues las cofradías al igual que las congregaciones eran uno de los pocos medios de expresión de los laicos en aquella Iglesia clericalizada- necesitaban de una instrucción para saber atender a los condenados. Juan Polanco, en su citada obra, puso interés en todo ello. Una atención espiritual que tenía que evitar que el condenado se sintiese abandonado hasta el momento de la ejecución, prolongándose esta asistencia con su familia. Incluso, en algunos lugares como Sevilla, los jesuitas facilitaban la comunión a los que iban a ser ajusticiados, después de su profundo arrepentimiento y confesión.

Pusieron los de la Compañía especial interés en la atención espiritual a los condenados como herejes por el tribunal del Santo Oficio. Cuando la Compañía desde Roma impulsó el establecimiento de la Inquisición en Portugal, se atribuyó a los jesuitas trabajos más espirituales que administrativos dentro de esta infraestructura. Entre ellos se encontraba la asistencia en la cárcel para dirigir a los presos tras su condena y, en algunos casos, antes de la ejecución de la pena capital. Los padres de la Compañía ya lo realizaron en Portugal en el Auto de Fe de Évora de 1553. Francisco de Borja se dirigió también el 20 de mayo de 1559, la víspera del famoso Auto de Valladolid, a Ana Enríquez, Agustín de Cazalla y el bachiller Herrezuelo, éstos dos últimos condenados a muerte $^{45}$. Otra cosa sería la intervención del jesuita Pedro de Tablares, aquel que era «propenso a inmiscuirse en todos los asuntos», en la polémica retractación del dominico fray Domingo de Rojas, protagonista del segundo Auto de Fe vallisoletano, el del 8 de octubre de $1559^{46}$. Uno de los privilegios con los que contaban los jesuitas en sus trabajos con la Inquisición y con herejes era la facultad de absolver [«in foro conscientiae»] a aquéllos que se retraían y arrepentían de sus opiniones heterodoxas. Era un privilegio muy útil para los jesuitas que trabajaban en las tierras de la Reforma, aunque los inquisidores de países católicos lo veían cómo una intromisión más de los religiosos de la Compañía en la jurisdicción de la Inquisición. Mientras que ésta pretendía la corrección del hereje a través de métodos más represivos, la Compañía contaba con los mismos objetivos pero con los medios más íntimos del sacra-

${ }^{45}$ ACSA, «Auto general de Fee», año 1559, leg. 202, f. 5v.

46 José Luis GonZÁLEZ Novalín, «El auto de fe de Valladolid de 1559. La ejecución de Domingo de Rojas. Personajes y circunstancias», Anthológica Annua 38, p. 598. José Ignacio TelLECHEA IDÍGORAS, «Perfil Teológico del protestantismo castellano del siglo XV: Un memorial inédito de la Inquisición (1559)», Diálogo Ecuménico 17 (1982), pp. 315-373.

Hispania Sacra, LXI

124, julio-diciembre 2009, 513-544, ISSN: 0018-215-X 
mento de la penitencia. Un privilegio que fue recortado aunque recuperado posteriormente ${ }^{47}$.

Los jesuitas también se hallaban presentes en días que eran considerados como heroicos, cuando atendían en las frecuentes epidemias que asolaban la Europa del momento. Juan Eusebio Nieremberg daba cuenta de aquellos que llegaban incluso a morir en el transcurso de estos trabajos y lo hacía en las páginas de los repertorios de Varones Ilustres. Por ejemplo, en la peste de 159899 -tan anunciada en visiones por una mujer tan próxima a los jesuitas como fue la mencionada Marina Escobar- la provincia castellana de la Compañía perdió un $12 \%$ de sus miembros. Los religiosos atendían en parejas a los pobres moribundos pero también a los más privilegiados, pues con serlo, no se libraban de la muerte. Las crónicas ponían énfasis en aquellas escenas que eran calificadas de «heroicas». Una de aquellas historias de los colegios de Castilla, la escrita de manera monumental por Pedro de Guzmán, relataba una escena estremecedora en el colegio de Santander ${ }^{48}$, cuando «en llegando a casa un herido de peste, bajaba un padre a la iglesia y le confesaba y comulgaba a cualquier hora que fuese porque, en acabando de comulgar, acontecía algunos morirse luego». Lo importante no era salvar la vida sino que, como hemos dicho ya en alguna ocasión, habría que conseguir que la muerte llegase sólo después de haberse confesado. El colegio de San Matías de Oviedo, que había sido fundado para atender una tierra aislada por las montañas como era Asturias, era menester que tuviese misioneros jesuitas preparados para salir a las aldeas más cercanas y llevar el viático a los enfermos, «llevando en el seno de una cajita de plata el Santísimo Sacramento para comulgar los enfermos»49. Aquellos eran los jesuitas que debían encontrarse preparados para enfrentarse directamente a la muerte. Las epidemias, esto también lo dijo Marina de Escobar para la peste de 1599 que en Valladolid supuso la muerte de algunas de sus autoridades -como la de su primer obispo, Bartolomé de la Plaza-, eran consideradas como un castigo divino, existiendo durante y después y entre los fieles, constantes deseos de practicar penitencia, de frecuentar los sacramentos, la confesión y la comunión. También, después de que los moriscos granadinos fuesen dispersados tras la revuelta de las Alpujarras de 1569, el padre Martín Gutiérrez, mientras permanecía en Salamanca, atendía a las moriscas que se encontraban gravemente enfermas.

47 Adriano Prosperi, Tribunali della coscienza, Inquisitori, confessori, missionari, Torino, Einaudi, 1996.

${ }^{48}$ ARSI, Pedro de GuZmán, Historia de la Compañía de Jesús de la Provincia de Castilla la Vieja, Castellana 35-I, f. 546v.

${ }^{49}$ Ibidem, f. 462v. 


\section{Enseñando a otros a «ayudar a bien morir»}

Esta parte del ministerio se entiende desde el ámbito teórico del ayudar a bien morir. La primera fuente de todo ello fueron los Ejercicios Espirituales, en las citadas meditaciones de la muerte que se incluían como hemos dicho en la primera semana. Pudiese ser que éstas no formasen parte de los inicios y que fuesen producto de las aportaciones posteriores que se fueron uniendo a las ediciones manuscritas que circularon por Castilla hasta la primera edición impresa en 1615. Con todo, los Ejercicios se diferenciaban de lo escatológico de su tiempo cuando destacaban la misericordia de Dios.

Precisamente, cuando aparecieron en imprenta un mayor número de manuales de «bien morir», escritos por autores jesuitas, fue cuando se introdujeron las mencionadas meditaciones de la muerte y del juicio en los Ejercicios Espirituales, material tan necesario en las misiones populares que empezaban a desarrollarse. Para ayudar a los que daban esos Ejercicios, Francisco de Salazar (15591599) escribió una de las obras más editadas y traducida del siglo XVI y en centurias posteriores. «Afectos y consideraciones devotas sobre los cuatro Novísimos» alcanzó las cien ediciones, llegando a ser traducida al tagalo en 1762. Salazar murió atendiendo a los moribundos de la peste de 1599 cuando se hallaba destinado en el colegio de León. Más tardía, aunque también vinculada a los Ejercicios Espirituales, fue la del jesuita vallisoletano Tomás de Villacastín, pues a un tratado sobre la obra espiritual de Ignacio de Loyola, añadió un breve apéndice «para ayudar a bien morir así a enfermos como a ajusticiados».

Los manuales de la buena muerte se dirigían a aquellas personas que querían preparar su propia muerte y no únicamente cuando se encontraban próximas a ella. Alonso de Andrade hablaba de la carta de navegación, que tenía que portar aquel que pretendía llegar hasta el «puerto de la Bienaventuranza» ${ }^{50}$. El libro se encontraba físicamente presente en el momento de la defunción, aunque solamente fuese en las manos del sacerdote, pero también a través de estos manuales que detallamos a continuación. Las páginas referidas a la muerte y escritas por Francisco de Borja bajo el título de «Algunos remedios para que los siervos de Dios no teman la muerte», aunque fueron escritas en sus últimos años como superior general, fueron publicadas después de haber fallecido. Se trataba de un folleto piadoso, convertida a juicio de John O'Malley en una «homilía patrística», pues las afirmaciones que en ella hacía, las fundamentaba en lo escrito por los Santos Padres, aunque ilustrado por la experiencia vital. Otro de los jesuitas de la primera generación, el importante visitador que fue Jerónimo Nadal, escribió unas Instrucciones para ayudar a los sacerdotes que trabajaban entre ago-

\footnotetext{
${ }^{50}$ Alonso de ANDRADE, Lecciones de bien morir y jornadas para la eternidad, Madrid, por Joseph Fernandez de Buendía, 1662, pp. 2-3.

Hispania Sacra, LXI

124, julio-diciembre 2009, 513-544, ISSN: 0018-215-X
} 
nizantes, considerando el valor que tenían estos trabajos, muy especialmente, entre los débiles y los ignorantes.

Una de las obras clásicas de este género fue la escrita y publicada por el que había sido el secretario de Ignacio de Loyola y sus sucesores, Juan de Polanco, con esa «Regla y orden para ayudar a bien morir», publicada en 1575. Sin duda, se convirtió en la obra más difundida, reeditada y traducida. Se dirigía hacia todos aquellos que sintiesen amenazada su vida, sin olvidar los consejos que llegaban a los familiares y amigos del enfermo. Existía en estas páginas algunos recuerdos de las antiguas «arts moriendi», aludiendo al demonio y sus tentaciones, al apego a lo terrenal, aunque se planteaba una suavización del terror.

Ya en el siglo XVII, el polémico Juan Bautista Poza publicaba en 1619 «Práctica de ayudar a bien morir, ahora nuevamente añadidos muchos ejemplos de santos». El carácter práctico de estas páginas se hallaba en que el autor aportaba soluciones para cada momento, tanto de carácter material como espiritual. La polémica caracterizó sus opiniones, según vimos en las anteriores afirmaciones referenciadas sobre el origen de las enfermedades lo que condujo a la prohibición de sus obras, enfrentándose además a un proceso inquisitorial en 1633, por sus teorías sobre la Concepción Inmaculada de María. La obra del padre Poza contaba con cierto paralelismo con las páginas del insigne predicador italiano, muy leído en España, Paolo Segneri (1624-1694). En su obra «El cura instruido», publicada en 1672, dedicaba un capítulo a la ayuda en el bien morir, debiendo mantener el sacerdote una presencia activa y eliminando los riesgos de las tentaciones.

Dentro de la misma línea argumental de Borja y Polanco, se encontraba otro de los pilares de la literatura jesuítica del «bien morir»: nos referimos al cardenal jesuita Roberto Bellarmino, cuya obra traducida al castellano por el doctor Lucas de Soria en 1640, aunque había sido publicada por vez primera en Roma en 1620. Significaba, eso sí, un punto de inflexión en el pensamiento de los jesuitas sobre la muerte, pues los destinatarios de estas páginas eran todos aquellos fieles cristianos que deseaban prepararse para una buena muerte. La obra de Juan Eusebio Nieremberg -«Partida para la eternidad»- se dirige a un público lector eminentemente culto, siendo un notable éxito aquella titulada «Diferencia entre lo temporal y lo eterno». En sus páginas, establecía que debía ir el cristiano ir eliminando progresivamente el apego a las cuestiones terrenales, a las comodidades de la vida, a su propia familia e hijos, pues todo ello suponía un préstamo que Dios le había hecho para servirle mejor. No trataba Nieremberg, con ello, de considerar poco importante el abandono de los próximos, sino más bien la necesidad de encomendarlos a Dios.

Una de las novedades del que pudiese ser uno de los últimos manuales jesuíticos en el «buen morir»-el de Francisco Arana- era la llamada a la prepara- 
ción constante ante la muerte. Una se conocía como la preparación próxima y otra la remota, además de la que tenía que desarrollarse durante toda la vida y que se podía conocer como preparación media. Afirmaba que no había que manifestar miedo a morir, sino más bien a hacerlo bien. Esa preparación media es la mayor aportación de Arana, metodología que ya habían popularizado las Congregaciones Marianas con los elementos propios del examen de conciencia y de la contemplación ignaciana. La metodología de los Ejercicios Espirituales lo inunda todo, recordando que aquella fue la primera propuesta de los jesuitas para aprender a bien morir. No serán los citados, sin duda, los únicos pues también podíamos incluir en esta producción a Esteban de Palma con «Las obligaciones del christiano a la hora de la muerte» (Roma, 1632) o «El espejo christiano del último instante entre la vida y la muerte» de Miguel Díaz (Madrid, 1718).

Los jesuitas no solamente enseñaban a «bien morir» a través de sus manuales, dirigidos a sacerdotes y a fieles cristianos, sino especialmente a los que componían las CONGREGACIONES que nacían desde la propia Compañía de Jesús. Establecidas en buena parte de las casas de los jesuitas, los congregantes no se dedicaban únicamente a las prácticas piadosas, sino también a los trabajos de caridad. Las Congregaciones se fueron especializando en diferentes tareas entre las que se encontraban las propias de ayudar a los moribundos en los hospitales, a los condenados en las cárceles, a acudir junto a los agonizantes en las calles, a entrar en los domicilios particulares o a asistir a los entierros. Una de las Congregaciones que se había establecido en el colegio de San Ignacio de Valladolid (hoy parroquia de San Miguel) fue la de la «Buena Muerte», ubicando en su capilla dos lienzos (del siglo XVIII) con las muertes humanas pero a la vez santas por excelencias: la Dormición de la Virgen María y sobre todo la Muerte de San José51. Aquella Congregación fue la titular de una de las imprentas de mayor importancia en el Valladolid del siglo XVIII.

En las reglas e indulgencias de la Congregación de Nuestra Señora de la Anunciata del Colegio Romano -y que se pueden aplicar a todas aquellas congregaciones que se asociaron a ella-, se hacía referencia a la actitud que los congregantes debían manifestar ante la muerte, la forma de ganar las indulgencias que se hallaban concedidas por los pontífices a la Congregación de «cabecera» - la prima primaria romana-, el acompañamiento que debían realizar al congregante enfermo, agonizante y fallecido. Congregaciones que contaban con un prefecto de enfermos, responsable de la salud corporal y espiritual de sus miembros. A estas congregaciones de los jesuitas se unieron otras cofradías y hermandades especializadas en hacerse cargo de los difuntos, de procurarles un entierro justo, sobre todo cuando habían sido ejecutados, debiendo atender también a sus fami-

51 Teófanes EgIdo LóPEZ, «La Devoción a San José en la Ilustración Española», en San José en el siglo XVIII. Estudios Josefinos, 89-90 (1991), pp. 439-441.

Hispania Sacra, LXI

124, julio-diciembre 2009, 513-544, ISSN: 0018-215-X 
lias. Ejemplo de ello en Valladolid, fuera del ámbito jesuítico, fue la cofradía de la Pasión de Cristo ${ }^{52}$ o la de las Angustias en lo referido al entierro de los muertos.

Para que los congregantes ayudasen a bien morir necesitaban de una guía para la adecuada preparación. Una de las más utilizadas fue la que escribió el padre Francisco Coster para los congregantes de Colonia, llegando la traducción española a principios del XVII. Esa guía destinada a los congregantes, para ellos mismos y para convertirse en maestros del buen morir, insistía en la incertidumbre de la muerte, en su infalibilidad, en las tentaciones que surgían en el que agonizaba (la desesperación unas veces, el exceso de confianza por otra, las dudas y los escrúpulos), además de los remedios que se habrían de poner contra el terror. Un tratado que para los congregantes, pretendía ser práctico, plagado para ello de ejemplos.

\section{DESPUÉS DE HABER TRASPASADO EL UMBRAL}

\section{Los escenarios de la tierra}

La muerte de un santo, en la tierra, se distinguía por su belleza, ó al menos así debía ser. Belleza en el rostro muerto, flexibilidad en el cuerpo como si acabase de expirar. Describía Nieremberg que, cuando en febrero de 1624, murió el jesuita Luis de La Puente en su Valladolid natal: «quedó su rostro más sereno que estando vivo, flexibles y tratables sus manos [...] y á menudo se veían los ángeles que rodeaban su cuerpo y le hazían como escolta» ${ }^{53}$. Esta naturalidad del cuerpo de un difunto era algo que siempre causaba asombro entre los que le rodeaban, convirtiéndose en signo de bienaventuranza. Buen olor permanente, incluso, después de meses en el sepulcro. Cuerpo muerto, santo y de buena fragancia susceptible de multiplicarse en las anheladas reliquias. El santo no podía ser enterrado como una persona más. Habitualmente, era trasladado poco tiempo después de su muerte a un lugar preferente y era entonces cuando se comprobaba el singular estado de conservación de algunas partes de su cuerpo. El esquema casi siempre fue el mismo:

«Fue sepultado [Luis de La Puente] en la manera que suele la Compañía enterrar a los santos varones; y después de diez y nueve meses á 18 de septiembre de 1625 , fue trasladado su cuerpo a otro más digno lugar, y aunque estaua la mayor parte comido; pero

52 Lourdes Amigo VÁzQUEZ, «Del patíbulo al cielo. La labor asistencial de la Cofradía de la Pasión en el Valladolid del Antiguo Régimen», en La Iglesia española y las instituciones de Caridad, Simposium celebrado en 2006, San Lorenzo de El Escorial, Instituto Escurialense de Investigaciones Históricas y Artísticas, 2006, pp. 511-542.

53 Juan Eusebio Nieremberg, Honor de San Ignacio..., ob. cit., vol. III, p. 514. 
(cosa que se atribuye a un milagro) sin rastro de mal olor quedó la cabeza incorrupta, enjutos y sin lesión los sesos» ${ }^{54}$.

«Al tiempo de ponerle en la sepultura [a Luis Gonzaga] fueron de parecer los Padres más graves del Colegio, y en especial el Padre Roberto Bellarmino que no era razón ponerle como á los demás en sepultura común, sino en otra, y metido en alguna caxa; porque aviendo sido su virtud y santidad tan rara, se podía pensar que Dios le avía de descubrir tanto más después de su muerte, quanto más se avía procurado esconder en vida. Pero porque en caxa era contra la costumbre de la Compañía, el Padre Rector embió al Ministro que fuesse á la Casa Professa á consultarlo con el Padre Lorenzo Magio, que á la sazón era Asistente de la Compañía por Italia y éste, aviéndolo tratado con él Padre General, embió a decir, que lo pusiesen en una caxa y que el Padre General dispensaba por esta vez de muy buena gana, por estar enterado de la singular santidad deste Hermano: prueba clara del grande concepto, que todos tenían de su santidad: pues se hizo con él una singularidad como ésta» ${ }^{55}$.

El predicador jesuita Agustín de Castro fue testigo en el entierro del trinitario descalzo Miguel de los Santos de la aclamación popular que los vallisoletanos de 1625 hicieron de la santidad de este fraile: «no solo no habían visto, pero ni oído jamás tan general aclamación de Santo»: «á la mañana temprano le baxaron [a fray Miguel de los Santos] á una sala que estaba en el claustro, con ánimo de enterrarle antes que en la ciudad se tuviese noticia de su muerte [...] quando apareció un tropel innumerable de gente de todos los estados á la puerta del convento, venciendo no solo la distancia que hay desde la ciudad, sino también un viento cierzo complicado con granizo [...] abiertas las puertas entró de tropel innumerable gente de todos los estados, y por instantes iban concurriendo más y más, así Religiosos de diversas órdenes, como Grandes, Ministros de justicia, hombres y mugeres de todas gerarquías» ${ }^{56}$.

En los santos, el final no podía reducirse a un sepulcro, aunque fuese muy peregrinado. Se leía en el colegio de ingleses de Valladolid la «Vida» del célebre misionero popular Juan Francisco Regis, incluida en la «enciclopédica» obra que el padre Andrade continuó, «Varones Ilustres». Regis era un misionero que fue beatificado por Clemente XI en mayo de 1716. Había muerto en el desarrollo de una de sus misiones, en tierras apartadas de Francia, en 1640. Al tratar de conducir los jesuitas su cuerpo a un colegio cercano de la Compañía, los aldeanos se pusieron en armas para detenerlos, no pudiéndole enterrar en otro sitio más que en la pobre iglesia de este lugar, «rica desde aquella hora, con tan precioso Tesoro y la que no era conocida en el mundo, se ha hecho de las más célebres y frequentadas del Reyno». Era la rentabilidad de una reliquia importante ${ }^{57}$.

\footnotetext{
${ }^{54}$ Ibidem.

55 Virgilio CEPARI, Vida de San Luis Gonzaga, Pamplona 1753, pp. 312-313.

${ }^{56}$ Fray Luis de SAn Diego, Compendio de la Vida del Beato Fray Miguel de los Santos, Madrid, 1782, pp. 285-286.

57 Alonso de ANDRADE, Varones Ilustres en santidad, letras y zelo de las almas de la Compañía de Jesús, Madrid, por Joseph Fernández de Buendía, 1666, vol. VI, p. 17.

Hispania Sacra, LXI

124, julio-diciembre 2009, 513-544, ISSN: 0018-215-X
} 
Después de las manifestaciones fúnebres más inmediatas, en un tiempo más sosegado se sucedían las honras fúnebres, celebradas por variadas religiones y en las que siempre los jesuitas contaban con un papel esencial. La manifestación de una muerte ejemplar de una persona dirigida por la Compañía de Jesús se ponía convertir en un magnífico recurso publicitario en favor de los trabajos de los jesuitas. Como mencionamos anteriormente, el conocido predicador Jerónimo de Florencia, desde su prestigio en la corte de Felipe III, aprovechó el sermón fúnebre de la reina Margarita de Austria en 1611 para hacer una dura crítica a la política del valido, el duque de Lerma.

Juan de Polanco había llamado a la moderación para evitar el boato exterior, eliminándose el carácter aparente de las exequias. Si estas honras se celebraban en un templo de los jesuitas, característico de las grandes celebraciones religiosas, como era a principios del siglo XVII la de la Casa Profesa de Valladolid -parroquia de San Miguel desde 1775-, los jesuitas debían resaltar el grado de hermandad o protección que había dispensado la Compañía a esa persona. Todo ello exigía una escenificación, un boato que, en ocasiones, no guardaba correspondencia a la exigida austeridad de la muerte, manifestada en los deseos del fallecido, que podía haberse dedicado en vida a los más necesitados, la elección de un hábito pobre para su mortaja, el reparto de limosnas -las últimas antes del testamento-. Honras fúnebres a las que podían asistir las más importantes instituciones del lugar. Con los años se acentúa lo ceremonioso, la ostentación, aunque las leyes pedían que se limitase bien todo esto.

El entierro de la gran fundadora de los colegios de los jesuitas, Magdalena de Ulloa, se vivió en el ámbito más íntimo de la Compañía, impidiendo la participación de otras instituciones. No ocurrió lo mismo con Marina de Escobar, hija espiritual de muchos jesuitas, entre ellos el citado Luis de La Puente. Máximo García resalta que, desde mediados del XVII, se produjo un «proceso de interiorización espacial», que ya reclamaban los jesuitas para sus miembros. Pero las honras de Marina de Escobar, en 1633, fueron diferentes cuando las distintas instituciones de la ciudad y del reino -ocurrió con la Chancillería- se disputaron sus presencias en los distintos momentos de las honras: «el rostro descubierto, porque todos le gozasen, con un vestido negro pobre y decente, que tenía guardado la difunta para aquel día, con un Jesús labrado al pecho, dando a entender que era hermana de la Compañía de Jesús y su hija espiritual» ${ }^{58}$. Disputas entre instituciones que continuaron cuando se trataba de discutir dónde depositar su cuerpo. De aquel ataúd, dos llaves las debía custodiar la Ciudad, otras dos el Cabildo Catedral y otras dos los jesuitas. Los capitulares propusieron la

58 Manuel CANESI, De la Historia Secular y Eclesiástica de la muy antigua, augusta, cornada, muy ilustre, muy noble, rica y muy leal ciudad de Valladolid. Historia de Valladolid (1750), Valladolid, Grupo Pinciano, 1996, vol. III, p. 254. 
posibilidad de que doña Marina fuese enterrada en la Iglesia Mayor, pero ella no había dado nunca otra opción que la de los jesuitas. Las Actas Capitulares no señalan nada a este respecto. «Suplico a los padres de la Compañía que me entierren como a uno de sus hermanos». Su testamento de marzo de 1624, nueve años antes de su muerte, indicaba claramente que su cuerpo fuese sepultado en la Casa Profesa de la Compañía, en el lugar que sus superiores fijasen, «como lo acen a vno de mis hermanos de la Compañía»59. La proclamación oficial de su santidad, que hubiese publicitado los trabajos de los jesuitas, se fue disipando con el tiempo. Ya escribió el entonces general de la Compañía a finales del siglo XVII, Tirso González, que estos casos de visionarias no gustaban nada en Roma.

El testamento también se hacía efectivo después de la muerte, aunque las disposiciones se dictaban antes del fallecimiento ${ }^{60}$. Ya lo escribió Juan de Polanco, «el que en la vida reparte lo que puede a los pobres y a lugares píos, podrá decir con San Lorenzo: «las manos de los pobres han llevado mis bienes a los cielos» ${ }^{61}$. La mejor defensa ante el tribunal que iba a juzgar a un fallecido eran las buenas obras. En el testamento, según insistía Borja, se solucionaban los asuntos pendientes con la familia, con los deudos, habiéndose dispuesto cómo habría de ser el duelo. En esta disposición se podía lograr la adecuada separación de las realidades temporales, llegándose a una adecuada preparación para el morir. Por eso, Jerónimo Nadal insistía en que había que dejar todo lo material bien atado en el testamento. Allí había que haber resuelto las obligaciones conyugales y filiales. Las limosnas hacia los más menesterosos no borraban las penas y pecados, aunque ayudaban a la bienaventuranza. Poza resalta que desde el testamento se podían haber solucionado enemistades pasadas, tratando de evitar escándalos. Bellarmino consideraba que las cuestiones testamentarias deberían estar resueltas antes de la propia enfermedad.

Las personas más privilegiadas tenían que buscar destinos más perpetuos para el carácter caduco de sus bienes, con el fin de alcanzar buenas obras que

59 «Testamento de Marina de Escobar», Valladolid, 2 marzo 1624, en Archivo Santa Brígida (en adelante ASB), caja $\mathrm{n}^{\circ} 2$, leg 4, doc. 4 .

${ }^{60}$ Antonio PeÑafiel, Testamento y buena muerte (Un estudio de mentalidades en la Murcia del siglo XVIII), Murcia, 1987. Marion ReDer, Morir en Málaga, testamentos malagueños en el siglo XVIII, Málaga, 1986. José Antonio RIVAS, Miedo y piedad: testamentos sevillanos del siglo XVIII, Sevilla, 1986. Máximo GARCÍA FERNÁNDEZ, «Vida y muerte en Valladolid. Un estudio de religiosidad popular y mentalidades colectivas: los testamentos», en La Religiosidad Popular, Barcelona, 1989, vol. II, Vida y muerte, pp. 224-243.

${ }^{61}$ Juan de PolanCo, Regla y orden para ayudar a bien morir a los que se parten de esta vida. Recopilada de las escrituras de muchos y píos doctores y confirmada con largo uso y experiencia. RP (en latín) y traducido al castellano por Pedro Simón Abril, Zaragoza, en casa de Juan Soler, 1578, f. 13v.

Hispania Sacra, LXI

124, julio-diciembre 2009, 513-544, ISSN: 0018-215-X 
habrían de hacerse con su hacienda, previendo un alcance espacial mayor y sobrepasando las necesidades, entonces actuales. Hacía una llamada de atención Polanco a la vanidad de los fundadores de grandes cosas con sus dineros, dispuestos después de la muerte: «y si fuera alguna obra perpetua, como hospital o monasterio, o cosa semejante, que mire no le mueva más el amor a la vanidad y de dejar memoria de sí que el amor de Dios y de los prójimos, dándole a entender que el que deja fundaciones perpetuas a los pobres, no habiendo necesidad notoria de socorrer a los pobres que se halla de presente tal que se deba preferir, alcanza mayor premio de mayor valor en su ser, que el que dejase limosnas del mismo valor por satisfacción de sus pecados» ${ }^{62}$.

Se establecía en la Regla $28^{\circ}$ de los sacerdotes jesuitas, que éstos no debían encontrarse presentes en el momento en que se hubiese dictado el testamento de sus dirigidos, evitando así una influencia en las decisiones que se tomasen, aunque eso no impedía la sugerencia de que se dedicasen parte de sus disposiciones a la atención de los más necesitados. Las Constituciones habían prohibido, también, a los jesuitas inmiscuirse en los «negocios seglares» propios de las últimas voluntades: «porque la Compañía más enteramente pueda attender a las cosas spirituales de su profesión, dexe, quanto fuere posible, todos negocios seglares (como de ser testamentarios o ejecutores o procuradores de cosas civiles o de cualquier manera), no admitiendo tales cargos, ni se ocupando en ellos por ruegos algunos» ${ }^{63}$.

En aquellas sacralizaciones había posibilidades muy diversas para ejercer la caridad, por lo que no estaba de más que se pudiese aconsejar de «hombres buenos, sabios y prudentes», llegando a ser alguno de ellos testamentarios, albaceas y ejecutores del cumplimiento de las disposiciones establecidas. Sabemos que esta disposición de no convertirse en testamentarios fue incumplida, o por lo menos, se concedió licencia en casos como el testamento de Magdalena de Ulloa o el de la condesa de Fuensaldaña, por aducir dos ejemplos transcendentales para los colegios de los jesuitas de Valladolid. La imagen de los jesuitas como testamentarios era la de la eficaz tarjeta de presentación ante la salvación. Para ella, los de la Compañía ofrecían los medios necesarios a través de las disposiciones de misas y obras pías a celebrar en sus iglesias o atendidas y vigiladas por ellos. Por eso, en los testamentos, se había especificado los remedios que se habrían de tomar para evitar ó acortar el purgatorio, a través de misas y aniversarios.

\footnotetext{
62 Juan de Polanco, ob. cit., f. 14r.

${ }^{63}$ Constituciones VI, $3^{\circ}, 591$, en Obras de San Ignacio..., ob. cit., p. 589.
} 


\section{Los escenarios extraterrenales}

En el uso de la imaginación, en las meditaciones, no todo era macabrismo. Naturalmente, el lugar para los bienaventurados era el cielo, sobre el cual (como ocurría con el infierno) existían detalladas descripciones. Desde la tierra poco podían conocer lo que Dios tenía preparado para los justos, en ese lugar considerado de gozo sin fin. Algo podían conjeturar por lo que había escrito el evangelista Juan en el libro del Apocalipsis, además de lo que habían podido sintetizar autores contemporáneos. Por ejemplo, el jesuita Gabriel Henao en su libro «Empirología». En esa misma línea habrían de situarse algunas páginas de Francisco Suárez, Roberto Bellarmino o Juan de Loyola, este último con su «Historia del Cielo Empyreo».

Cuando el hombre o la mujer morían, el Ángel de la Guarda que le había asistido en esa hora, conducía su alma al Reino de los Cielos. Acompañado de otros ángeles y santos le presentaba ante el Trono de Dios. Concluida esta audiencia pasará el bienaventurado al palacio de la Virgen María, a los de los ángeles y santos de los que fue devoto, ante sus padres, amigos y bienhechores. En el caso de los jesuitas difuntos se presentará ante san Ignacio: «De qué asuntos hablarán con el Santo Padre; y este de que les hablará? Piénselo cada uno de nosotros; porque esta materia es interminable» ${ }^{64}$.

En las descripciones del cielo no podía faltar su geografía, sus regiones, su extensión infinita, identificándose a la luz con Dios, no comprensible con los ojos humanos. Un bienaventurado, su cuerpo y su alma, luce según estas descripciones, cincuenta o sesenta veces más que el sol material. Pero Dios brillaba más que todos los bienaventurados juntos, añadía Juan de Loyola. Era la santidad infinita, la perfección infinita, la sabiduría infinita, la bondad infinita, el poder infinito y la inmensidad infinita. El empleo de estos ciudadanos del cielo era únicamente la constante alabanza a Dios. Los celestiales festines, donde no faltaba la comida (aunque no con los manjares terrenos) estaban amenizados por instrumentos que eran interpretados con gran primor. Y reflejo de estas fiestas celestiales, y de ahí saldrá una idea importante, serán las sacras de la tierra. Los bienaventurados se gozarán con las fiestas celebradas por la Iglesia Triunfante. Se alegrarán en las fiestas del Corpus en la tierra, aunque celebrarán eternamente la Eucaristía en el cielo:

«Un día después de la octava del Corpus, ví a NPS. Ignacio vestido -escribía Luis de La Puente la visión de Marina de Escobar sobre la procesión del Corpus- no como suelo verle con vestiduras, que ordinariamente trahen sus Religiosos; sino como sacerdote con

${ }^{64}$ Juan de Loyola, Historia del Cielo Empyreo, Valladolid, imprenta de la Congregación de la Buena Muerte, 1755, p. 282.

Hispania Sacra, LXI

124, julio-diciembre 2009, 513-544, ISSN: 0018-215-X 
una capa plegada por arriba, como la que se ponen, quando llevan el Santísimo á algún enfermo, la qual estaba toda llena, y sembrada de muchos nombres de Jesús hechos, y bordados de un oro tan rico, y resplandeciente, que cada nombre parecía un sol muy claro, y de gran resplandor, y cada vno estaba metido dentro de un círculo de muchos rayos. Tenía el Santo en sus manos una Hostia, la qual unas veces veía en su propia forma, y otras veía un Niño santíssimo en ella, á quien las especies sacramentales servían como velo. Como vi de esta manera tan nueva al Santo Patriarcha, retirávame, como suelo hacerlo, quitaba los ojos de aquello, que se me ponía delante y estaba pensando que podía ser aquello. El glorioso Santo, aunque veía, y penetraba lo que passaba en mi corazón, callaba y disimulaba, sin hacerme mucha fuerza para que le viesse, antes se apartaba un poco, hasta que Nuestro Señor, como suele hacerlo, me quitase aquel modo de temor, que tenía, y me dispusiesse para poder ver el mysterio, que pretendía mostrarme. Passando un rato, como ya Nuestro Señor me tuviesse dispuesta, bolvió NPS. Ignacio á ponérseme delante de la misma manera, y vile con mucha mayor luz y claridad y también el mysterio, que se ha dicho y que estaba allí mucha gente, como quando se juntan muchos en una Iglesia, donde ay una solemne fiesta, o processión, más no reparé, que gente era, por estar suspensa, mirando el mysterio, que tenía presente, sin saber bien lo que era. Entonces me dixo Nuestro Señor: esto he querido mostrarte para que sepas que en el Cielo este día los Santos Bienaventurados que vivieron en la tierra y gozaron de los admirables frutos de este divino Sacramento, celebran también la fiesta de su Institución con grandíssimo gozo, y alegría, y hacimiento de gracias por tan especiales dones, y soberana merced, como les fue hecha y dada en la tierra, y como mi siervo Ignacio fue tan particular en la devoción, que siempre tuvo al nombre de Jesús, cuyo nombre es del Señor de esta fiesta; pues por esta devoción suya le tomó por su ayuda en todas las obras, que hizo y apellidó con él su Religión, se le hace esta particular honra, de que entre los Santos del Cielo, él haga este ministerio» 65 .

Ambas fiestas, las celestiales y las terrenas sacralizadas, contienen los mismos elementos: luminarias, banquetes, representaciones, bailes, danzas y saraos. Y así, después de haber meditado con el padre La Puente sobre las postrimerías de este mundo, Juan de Loyola presentaba un cielo cargado de sensualidad sagrada. Los sentidos alcanzaban en estos espacios su plenitud. Los bienaventurados se hallaban perfeccionados de todo lo grosero. Gozo en la vista de ver cuerpos gloriosos, sin necesidad de contactos carnales. Se preguntaban cómo eran las conversaciones, siempre santas, discretas y gustosas. Contaban los ángeles con su idioma particular, aunque todavía algunos se preguntaban si conocían la lengua hebrea o la latina. Lo más probable, dice el padre Loyola, es que hubiesen cesado los idiomas terrenos y Dios habrá infundido a los bienaventurados una lengua celeste. Por algo, los ángeles habían hablado con los santos cuando éstos habían permanecido en la vida terrena.

El cuerpo de los bienaventurados resucitará, volverá el alma a entrar en su cuerpo. Lo harán vestidos de claridad, luz y gloria a semejanza del cuerpo de Jesús. Los predestinados podrán conversar los unos con los otros, viviendo eter-

${ }^{65}$ Luis de La Puente, Vida Maravillosa..., ob cit, p. 244. 
namente sin el menor dolor, tristeza, aflicción, pena, disgusto e inundados de todas las felicidades que se pudiesen esperar. No habrá muerte en adelante. A la resurrección de los bienaventurados, seguirá la renovación de todas las criaturas, como indica santo Tomás de Aquino. Con todo ello, por lo tratado por estos predicadores, teólogos y escritores, el cristiano no debía mostrarse de otra forma que ansioso por llegar a esta «Celestial Jerusalén, Corte del Cielo Empyreo», como había manifestado san Agustín.

Pero, la salvación no era un camino fácil, al menos la vida del cristiano era concebida como un continuado camino de obstáculos que había que superar, bajo la presencia continuada del pecado. Al menos a esta conclusión podemos llegar si leemos las obras del misionero popular jesuita, muy conocido en su siglo XVIII, Pedro de Calatayud ${ }^{66}$. Vida angustiosa y vigilada había sido la del cristiano, porque Dios todo lo veía y «nada se le ocultaba». Por eso, inmediatamente unido al concepto de pecado se encontraba el de castigo. El gran castigo de Dios, en opinión de este misionero, era la libertad de dejar al hombre cometer sus apetencias, para poder posteriormente hacerle pagar en la eternidad con ese infierno: infierno, purgatorio, cielo y juicio final, una graduación de lugares que comenzaba por el «Limbo de los Santos Padres»:

«Pregunta: Ay en el infierno más tormentos que el fuego?

Respuesta: Ay muchísimo y diversos para todos los miembros, sentidos y potencias de el condenado, y entre otros es terrible el gusano roedor de la conciencia que es la continua memoria de las ocasiones y bienes que malogró y de los males que por su gusto incurrió» 67 .

Añadía Calatayud, la existencia de otras «cárceles en el centro o entrañas de la tierra», como el Limbo de los Niños, destinado para aquéllos que morían en estado de pecado original al no haber sido bautizados. Muerte cuya culpa se la atribuyó el jesuita, en muchas ocasiones, a las madres que querían ocultar a su hijo para evitar la marginación social de un embarazo no deseado. El purgatorio era el lugar destinado para aquellas almas que morían en gracia de Dios, pero que todavía no habían satisfecho la pena de los pecados cometidos. Para evitar el purgatorio, en su cotidianidad, el cristiano debía evitar las faltas leves, practicar la necesaria penitencia, los ayunos, las oraciones y limosnas y considerar la ganancia de jubileos e indulgencias. La auténtica meta a la que debía aspirar todo cristiano era ese Cielo que había descrito Juan de Loyola.

\footnotetext{
66 Javier BURRIEZA SÁNCHEZ, «Un catecismo jesuítico en la España de la Ilustración. Pedro de Calatayud y la catequesis de la Compañía de Jesús», Investigaciones Históricas 19 (1999), pp. 53-80.

${ }^{67}$ Pedro de Calatayud, Cathecismo Práctico y mui útil para la instrucción, y enseñanza fácil de los Fieles, y para el uso, y alivio de los Señores Parrochos, y Sacerdotes, Valladolid, imprenta de la Congregación de la Buena Muerte, 1747, pp. 152-153.
}

Hispania Sacra, LXI

124, julio-diciembre 2009, 513-544, ISSN: 0018-215-X 
La imagen de Dios como juez, en su Juicio Final, era la demostración del gobierno de Dios sobre el mundo y de su auténtica justicia, cuando en la vida terrena algunos no habían recibido su verdadero premio y otros su auténtico castigo. En el momento de la muerte, Pedro de Calatayud hablaba de un juicio secreto e invisible. No estaba exenta la muerte de un religioso, por ejemplo de la Compañía, de sentimientos de temor ante el juicio de Dios. Así fue retratado Antonio de Padilla, catedrático en el colegio de San Ambrosio de Valladolid:

«Tenía mucho temor de morirse, por la cuenta que había de dar a Dios y con este temor le decía: «si vos, Señor, lo hubiésedes de hacer conmigo tan cortamente como yo lo he hecho con vos, mucho trabajo tendría yo». Viéndole un Padre tan temeroso, le preguntó que si le remordía la conciencia de algún pecado mortal de cuarenta años que había estado en la Compañía; y él respondió: «Jesús, qué monstruosidad tan grande! ¿Religioso y pecado mortal? No hay que tratar de eso» ${ }^{68}$.

Previo a la celebración del Juicio Final se debía producir la resurrección de los muertos. Entonces las palabras del misionero popular se convirtieron en seguras descripciones de unas escenas que, parecía haber contemplado anteriormente:

«El cuerpo del condenado [en la resurrección de los muertos] quedará horrible y todo él encendido en fuego; el de el escogido resucitará glorioso y con los quatro dotes de gloria; con el dote de agilidad, quedará despojado de todos los humores, que le hacían pesado y tardo y más ágil que el Sol en su movimiento: con el dote de sutileza quedará más sutil y delicado, que la mesma luz y se podrá penetrar por los cuerpos opacos, como el de Christo se penetró en su Resurrección con la piedra de el Sepulcro: con el dote de impasibilidad quedará inmortal y libre de padecer hambre, sed, dolores, frío, calor y otras modestias, que le afligían en vida: por el dote de claridad se ha de bolver más hermoso y resplandeciente que el Sol» 69 .

Con semejantes descripciones, las perspectivas del más allá se encontraban lo suficientemente fijadas como para ponerse manos a la obra desde las conductas del más acá. Después de escuchar los asistentes, en las misiones populares estas descripciones, poco importaba que el pecador no fuera castigado inmediatamente, durante su existencia terrena. La justicia de Dios le esperaba para otros momentos, sin existir lugar para la duda y el escepticismo.

La buena muerte era una adecuada señal para empezar a reconocer la santidad de un individuo, propiciando la comunión de los santos la intercesión salvífica de los que la necesitaban. Si la Compañía de Jesús se presentaba como ins-

${ }^{68}$ Luis de LA PuENTE, «Vida del P. Baltasar Álvarez», en Biblioteca de Autores Españoles, $\mathrm{n}^{\circ} 111$. Obras escogidas del VP. Luis de La Puente de la Compañía de Jesús; estudio, edición, notas del P. Camilo María Abad, Madrid, 1958, p. 107.

${ }^{69}$ Pedro de Calatayud, Cathecismo Práctico..., ob. cit., pp. 152-153. 
trumento para alcanzar este objetivo, los jesuitas trataban de demostrar a través de sus trabajos y junto al lecho del moribundo, por las obras que escribían e imprimían sus autores de éxito y por la publicística que realizaban de todo ello, que los medios que ofrecían se presentaban más seguros y eficaces que otros ya planteados y existentes. Enfatizaban que su espiritualidad contribuía a culminar un deseo de salvación manifiesto. Se cumplía el objetivo de la Compañía: no solamente procuraban por su vida espiritual alcanzar su propia salvación sino también la de los prójimos. De todas las maneras, la atención a los agonizantes no era una finalidad por sí misma o una especialización pastoral. Se convertía en un medio más para alcanzar el objetivo primigenio de la Compañía. No obstante, ocurrió lo que en otros campos pastorales: la racionalización y desarrollo de los jesuitas fue tan efectivo y convenientemente publicitado, que la atención prestada a los moribundos se convirtió, no sólo en una especialización, sino que también creó de los jesuitas una imagen propia. No facilitaban únicamente un «pasaporte» más seguro hacia la anhelada salvación sino también la creación de una imagen estereotipada de la atención de los de la Compañía ante la muerte: no siempre presidida por una caridad que ejercían las más de las veces, por un discurso reconfortante capaz de generar confianza y un arrepentimiento sincero, sino por las ambiciones orientadas a captar ciertas fortunas económicas que bien podrían facilitar la expansión de los colegios de los jesuitas. De ahí, las prevenciones, no siempre cumplidas, y dispuestas por los superiores de la propia Compañía, por evitar que sus «operarios» ejerciesen un papel determinante en las disposiciones de los testamentos. 